\title{
Leon Deben
}

In de rubriek Klassiekers gaat AGORA in op boeken die niet vers van de pers komen, maar nog steeds uiterst relevant zijn. Deze keer 'Stadt im Wandel - Eine Wiederholungsuntersuchung der Stadt Wolfsburg nach 20 Jahren' van Herleyn, Schweitzer, Tession en Lettko (1982).

Toen ik met collega socioloog Kees Schuyt en een tiental studenten in 2000 het onderzoek 'Sociale cohesie in Almere, sociale samenhang in een jonge stad' uitvoerde, herinnerde ik mij de studie van Ulfert Herlyn over de stad Wolfsburg. Net als Almere een vrijwel vanuit het niets geplande stad. Sinds de jaren tachtig had de stadssociologie haar oriëntatie verbreed naar de invloed van industrialisatie, verstedelijking en bureaucratisering op het leven van de bewoners. Eerdere studies waren vrij beperkt en betroffen in Nederland vooral bouwen en wonen. Nu ging het over vragen als: hoe richten mensen in een stad hun dagelijkse leven in? Waar werken en wonen ze? Wat doen ze in hun vrije tijd?

\section{Wat doet de stad je aan?}

Ondanks deze verandering in perspectief in de jaren tachtig blijft stadssociologisch onderzoek nog steeds vaak beperkt tot een momentopname met weinig aandacht voor een in de tijd doorlopend ontwikkelingsperspectief. Wilmott omschreef dat reeds in 1965 met 'time is left out'. Gelukkig zijn er uitzonderingen, zoals 'The Levittowners - Ways of Life and Politics in a New Suburban Community' uit 1967 door Gans; het onderzoek van Gadourek over het dorp Sassenheim, 'A Dutch Community' uit 1965; en tot slot, Herlyns ontwikkelingsstudie van de Duitse stad Wolfsburg, oftewel de 'Goldgraberstadt'.

De geschiedenis van deze stad begint in 1938 als ze als 'die Stadt des KDF Wagens (de voorloper van de VW-kever)' wordt aangewezen. De Volkswagenfabriek is de goudader van de stad. De inrichting van de stad is dan ook vooral gericht op deze fabriek. Dit was reden voor Herlyn en collega's om twee keer onderzoek te doen in de stad: in de periode 1959-1967 ('Wolfsburg') en in de jaren 1979-1982 ('Stadt im Wandel'). Centraal in deze studies stond de invloed van een dominante industrie op het leven van de inwoners.

In 'Wolfsburg' pogen de onderzoekers inzicht te verschaffen in de ontwikkelingsgeschiedenis en het wordingsproces van de stad - die toen nog slechts bestond uit één straat: de Porsche-strasse, een brede zesbaansweg met parkeerstroken en winkels. De onderzoekers slaagden er echter maar deels in de beloofde ontwikkelingsprocessen in kaart te brengen, deels omdat het slechts een momentopname betrof. Herlyn en collega's besloten daarom twintig jaar later een nieuwe poging te wagen hun onderzoeksvraag te beantwoorden. Dit doen ze in 'Stadt im Wandel', waar de verwevenheid tussen de ontwikkeling van Wolfsburg en die van de Volkswagenonderneming wordt beschreven. Dit met hulp van het bewaarde materiaal uit het eerdere onderzoek: adressen en enquêtes, panelstudies, interviews met sleutelpersonen en subjectieve levensgeschiedenissen. Deze verwevenheid komt op verschillende manieren in het dagelijks leven naar voren: de sportclubs zijn door het bedrijf gefinancierd en het museum is door de 'Kunststiftung Volkswagen' en de 'Holler-stiftung' (eigenlijk ook Volkswagen) gefinancierd onder het motto 'Kunst für Alle'. Een vergelijkbaar Nederlands voorbeeld is de invloed van Philips op de bevolking van Eindhoven.

Herlyns studie is een goed voorbeeld voor onderzoekers die de ontwikkeling en de ontstaansgeschiedenis van een plaats willen bestuderen en biedt daarmee aanknopingspunten voor toekomstige studies. Ten eerste geeft de verkenning van de relatie tussen de stad als woonplaats en de individuele perspectieven van haar bewoners inzicht in 'wat de stad je aandoet' en wat het betekent geboren te zijn en op te groeien op een bepaalde plaats met haar specifieke voorzieningen. Zo waren de bewoners van Wolfsburg voor een groot deel van hun leven - van hypotheekverkrijging tot het volgen van een vakopleiding - afhankelijk van Volkswagen. Ten tweede toont deze studie het belang aan van het onderzoeken van de ontwikkeling van de beleving van een stad over een langere periode van tijd. Hoe zijn leefwijze en toekomstperspectieven veranderd? Zijn bewoners zich thuis gaan voelen in hun geplande wereld? Net als de Almeerders zijn de inwoners van Wolfsburg - door de uit Frankfurt verhuisde werknemers ooit Siberië genoemd - nu trots op hun stad en hoeven niet meer uit leggen waarom ze er wonen.

Leon Deben (deben@chello.nl) is voormalig hoofdmedewerker stadssociologie en verbonden aan de Universiteit van Amsterdam, afdeling Sociologie en Antropologie. 